\title{
Using geometric morphometrics and standard morphometry to discriminate three honeybee subspecies*
}

\author{
Adam TOFILSKI \\ Department of Pomology and Apiculture, Agricultural University, 29 Listopada 54, 31-425 Krakow, Poland
}

Received 12 February 2008 - Revised 21 May 2008 - Accepted 23 May 2008

\begin{abstract}
Honeybee (Apis mellifera) subspecies usually are distinguished by standard morphometry methods, based mainly on multivariate analysis of distances and angles. Recently another method of statistical analysis of shape, geometric morphometrics, has been developed. The new method is based on characteristic points described by Cartesian coordinates. The two methods were used here to discriminate three honeybee subspecies (A. m. mellifera, A. m. carnica and A. m. caucasica) according to forewing venation. Forewing venation was described either by coordinates of 18 vein junctions and centroid size or by 4 distances and 11 angles. All colonies, described by mean of 10 workers, were correctly classified using both methods. In the case of individual wings discrimination, geometric morphometrics was $84.9 \%$ successful and standard morphometry was $83.8 \%$ successful. The results show that geometric morphometrics is marginally more reliable than standard morphometry for discrimination of honeybee subspecies.
\end{abstract}

geometric morphometrics / standard morphometry / subspecies discrimination / Apis mellifera

\section{INTRODUCTION}

Many geographic races or subspecies of the honeybee (Apis mellifera L.) occur within its wide range of natural distribution. They differ in many traits, both behavioural and morphological. Originally, discrimination of subspecies was based on descriptive methods, but they proved insufficient and were replaced by morphometric methods (Ruttner, 1988a). Morphometric methods are based on multiple measurements of many individuals (Alpatov, 1929). Interpretation of the measurements was difficult without multivariate statistical methods, which were introduced by DuPraw (1964). Of the large number of characters used in earlier studies, Ruttner et al. (1978) chose 42 characters for analysis of honeybee workers from a wide range of geographic locations. This set of characters, called "standard morphometry", stood the test of

Corresponding author: A. Tofilski, rotofils@cyf-kr.edu.pl

* Manuscript editor: Stefan Fuchs time and continues to be the method most often used in a wide range of studies of geographic variation (Ruttner et al., 2000; Radloff et al., 2003; Diniz-Filho et al., 2000). The standard morphometry characters include distances, angles and discrete classes of pigmentation.

Statistical shape analysis theory has made significant advances in recent years. The new method, often called "geometric morphometrics" (Bookstein, 1991), is based on a wellestablished theory of shape (Kendall et al., 1999). Instead of distances and angles it uses the coordinates of points called landmarks. The landmarks are superimposed by translation, scaling and rotation. After superposition the landmark configurations differ only in shape, and can be analyzed by multivariate statistical methods (Zelditch et al., 2004).

Honeybee subspecies can be very precisely discriminated using molecular methods (Whitfield et al., 2006), but those methods are not easily accessible to beekeepers as the services of molecular laboratories are expensive. Morphometric methods are much more 
available. Currently beekeepers discriminate European subspecies by measuring only a few morphological characters, including cubital index, proboscis length, and colour marking on abdomen (Ruttner, 1988b; Rostecki et al., 2007). Discrimination could be significantly improved through the use of all characters of standard morphometry, but manual measurements of multiple characters are timeconsuming, so beekeepers rarely take advantage of standard morphometry. One solution is to increase the number of wing measurements because, unlike other body parts, wings can be measured automatically (Tofilski, 2007; Steinhage et al., 2007). Automatic measurements of wings are quick and precise (Tofilski, 2007). They require only access to a scanner and a personal computer. Some beekeepers already use automatic measurements to determine the cubital index.

The aim of this study was to compare the effectiveness of geometric morphometrics and standard morphometry as methods for discriminating honeybee subspecies based on forewing venation. Venation was described either by 4 distances and 11 angles or by the coordinates of 18 points and centroid size.

\section{MATERIALS AND METHODS}

Three honeybee subspecies collected from queen breeding apiaries in Poland were studied: Apis mellifera carnica Pollmann, Apis mellifera caucasica Gorbachev and Apis mellifera mellifera L. Each subspecies was represented by 300 workers from 30 colonies (10 workers per colony). The left forewing of each worker (total 900 wings) was dissected, mounted in glass photographic frames (Rowi 260) and scanned with a Nikon Coolscan 5000 ED scanner equipped with an SF-210 slide feeder (image resolution $2400 \mathrm{dpi}$ ). For every wing image the coordinates of 18 vein junctions (Fig. 1A) were determined automatically using DrawWing software (Tofilski, 2004). The vein junctions were used as landmarks for geometric morphometrics. The landmarks were aligned according to generalized orthogonal least-squares procedures (Rohlf and Slice, 1990) using tspSuper software (Rohlf, 2004). Centroid size (Zelditch et al., 2004) was used as estimate of wing size in geometric morphometrics. The centroid size was calculated using land- marks coordinates measured in millimetres. Standard morphometry was based on 4 distances and 11 angles. Apart from lengths of cubital veins "a" and "b" distances "c" and "d" were used, as suggested by Dedej and Nazzi (1994), to estimate wing width and length. Those variables were calculated from the coordinates of the 18 landmarks using trigonometric functions. To describe a colony, all variables were averaged across 10 workers from the colony.

Forward stepwise discriminant function analysis $($ tolerance $=0.01 ; \mathrm{F}$ to enter $=1.0)($ StatSoft, 2001) was used to determine classification functions, followed by canonical analysis. The discrimination was based on the 18 aligned landmark coordinates and centroid size or 4 distances and 11 angles. The contribution of the different variables to canonical variables was assessed using standardized coefficients. Differences between subspecies were tested using MANOVA of partial warp scores produced by the tpsRelw software package (Rohlf, 2005). Cross validation test was used to verify the accuracy of both methods. In the cross validation test half of colonies were used as training set and the other half of colonies were used as validation set.

\section{RESULTS}

\subsection{Discrimination of colonies}

Using stepwise discriminant function analysis, 13 of 15 variables were incorporated into the classification model based on standard morphometry. Using the same statistical methods, 22 of 37 variables were included in the classification model based on geometric morphometrics. Canonical variate analysis based on both methods separated the subspecies into three non-overlapping clouds of points (Fig. 2A, B). The first canonical variable discriminated mainly between A. m. carnica and A. m. mellifera. The variables that contributed most to the first canonical variable were distance $b$ from standard morphometry and coordinate $6 \mathrm{Y}$ from geometric morphometrics. The second canonical variable mainly discriminated between A. $m$. caucasica and the other two subspecies. The variables that contributed most to the second canonical variable were angle B4 from standard morphometry and coordinate $12 \mathrm{X}$ from geometric morphometrics. 

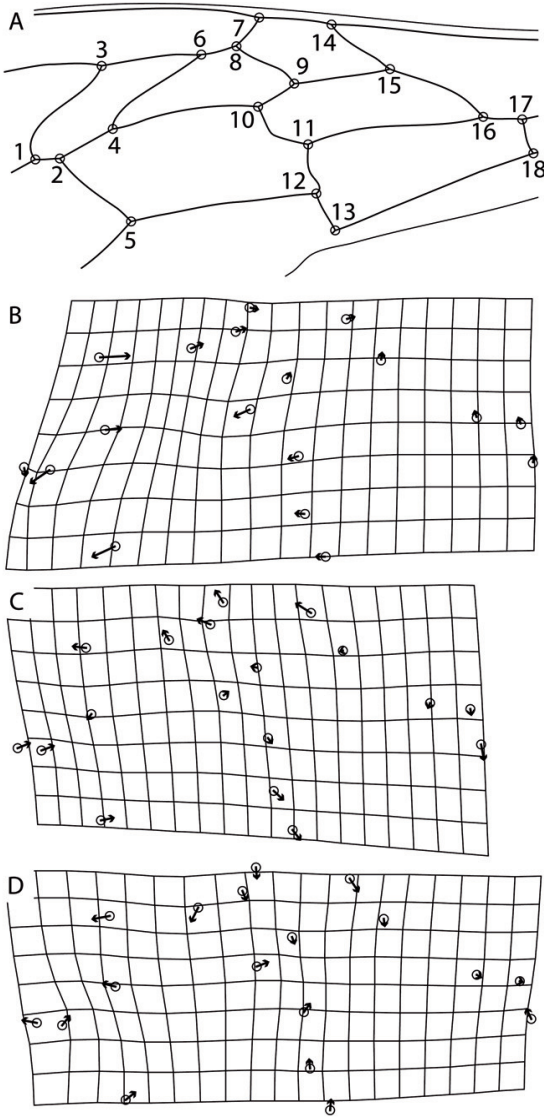

Figure 1. Honeybee forewing diagram with the vein junctions numbered (A), and deformation grids for three subspecies: A. m. carnica (B), A. m. caucasica (C) and A. m. mellifera (D). Nonlinearity of the deformation grids indicates differences between the average wing of the three subspecies and the wing of a particular subspecies. The circles correspond to vein junctions, and the arrows attached to them indicate the magnitude and direction of the difference between the average wing and the wing of a particular subspecies. Differences between the subspecies were exaggerated 5 times to make them more visible.

All colonies were classified correctly using both the classification functions based on standard morphometry (Appendix I) and geometric morphometrics (Appendix II).

Shape of forewing venation differed significantly between the three subspecies (MANOVA: Wilks' Lambda $=0.0115$;
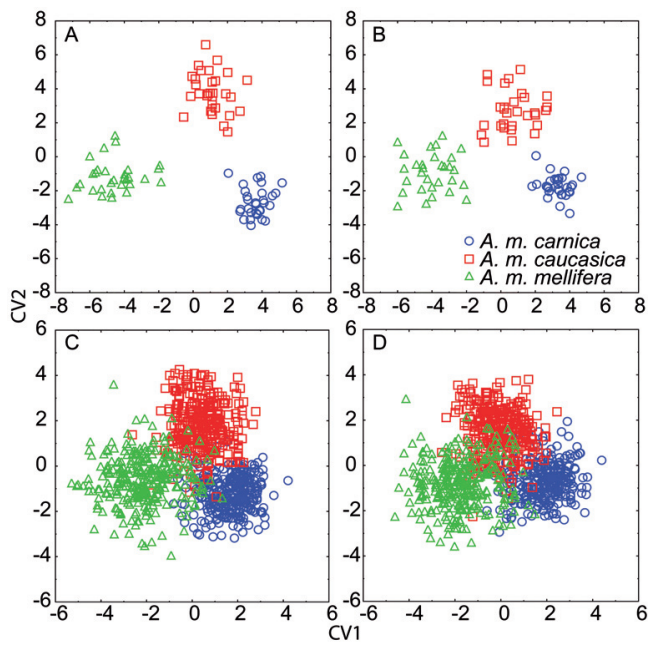

Figure 2. Discrimination of three honeybee subspecies (A. m. carnica, A. m. caucasica, A. m. mellifera) based on geometric morphometrics $(\mathrm{A}, \mathrm{C})$ and standard morphometry (B, D). Either the means of 10 workers from one colony (A, B) or single wings $(C, D)$ were used for discrimination. The horizontal and vertical axes correspond to the first and second canonical variables, respectively.

$\left.F_{42,134}=26.57 ; P<0.0001\right)$. Differences between the subspecies are illustrated by deformation grids (Fig. 1B, C, D). The Procrustes distances were $2.68 \times 10^{-2}$ between $A$. m. carnica and A. m. caucasica, $2.58 \times 10^{-2}$ between A. m. carnica and A. m. mellifera, and $1.92 \times 10^{-2}$ between $A$. m. mellifera and $A$. m. caucasica. Within subspecies A. m. carnica, A. m. caucasica and A. m. mellifera the Procrustes distances (mean \pm $\mathrm{SE)}$ were $1.17 \times 10^{-2} \pm 4.86 \times 10^{-4}$, $1.60 \times 10^{-2} \pm 6.86 \times 10^{-4}$ and $1.48 \times 10^{-2} \pm 5.10 \times 10^{-4}$, respectively.

\subsection{Discrimination of single wings}

Using stepwise discriminant function analysis, all 15 variables were selected to be included in the classification model based on standard morphometry. Using the same statistical methods, 29 of 37 variables were selected for inclusion in the classification model based on geometric morphometrics. Canonical variate analysis based on both methods 
separated the subspecies, but the clouds of points representing subspecies overlapped to some degree (Fig. 2C, D). The classification functions based on standard morphometry (Appendix III) classified individual wings less accurately than the functions based on geometric morphometrics (Appendix IV). The proportions of individual wings correctly classified using standard morphometry and geometric morphometrics were $86.3 \%$ and $90.6 \%$, respectively. In cross validation test the proportion of wings correctly classified using standard morphometry and geometric morphometrics was $83.8 \%$ and $84.9 \%$, respectively. The classification of individual wings was less precise than the classification based on mean of 10 wings from one colony.

\section{DISCUSSION}

The results presented here show that geometric morphometrics yielded marginally better discrimination of honeybee subspecies than standard morphometry. The differences in the discrimination were found only when it was based on individual wings. In case of discrimination of colonies no differences were found because both methods correctly classified all colonies. Better discrimination of subspecies based on geometric morphometrics compared to standard morphometry is not surprising, as the former used 37 variables as opposed to the 15 variables of standard morphometry. When a large number of variables are used, some of them become redundant because of the correlations between them. This problem can be solved by stepwise discriminant analysis, which selects for the classification model only the variables that contribute significantly to the discrimination. On the other hand, the variables used in standard morphometry have been chosen mainly because they proved effective in earlier studies (Ruttner, 1988a). Almost all of those variables contributed significantly to the discrimination. Only in the classification of colonies were two variables (distance $\mathrm{c}$ and angle J16, Appendix I) found redundant by stepwise discriminant analysis. There are a large number of possible angles and distances calculable using vein junctions, and the choice of those used in standard morphometry is largely arbitrary. Choosing different sets of angles and distances might produce slightly different results.

The use of fewer variables might be justified by the amount of work required to obtain the data. However, the same amount of time is required to collect the raw data for both methods. In this study standard morphometry was based on 15 variables, but the coordinates of all 18 vein junctions needed to be known before the 11 angles and 4 distances could be calculated.

Geometric morphometrics allowed differences between subspecies to be plotted as vectors and a deformation grid (Fig. 1B, C, D). It is easier to interpret those plots than to compare many distances and angles. The deformation grid identifies the wing regions that contribute most to the discrimination. For example, in A. m. carnica the cubital index is relatively large, mainly due to differences in the position of vein junction number 2 (Fig. 2B).

The classification functions presented here can be used to discriminate subspecies. Unfortunately, the classification functions usually are not published, even when discriminant function analysis is used (Kauhausen and Ruttner, 1986; Radloff and Hepburn, 2000). To assign a colony to one of the three subspecies, a sample of wings from one colony should be obtained and 18 landmarks should be determined. The average configuration of the landmarks should be calculated and superimposed on the reference configuration representing mean position of the landmarks in all subspecies (Appendix VI). The superimposed landmarks should be taken together with the discrimination functions to calculate the score for each subspecies. The colony should be assigned to the subspecies with the highest score. To confirm the assignment, the Procrustes distance between the tested colony and the subspecies to which it was assigned should be calculated. If that distance is significantly larger than the values presented here, the tested colony is either a hybrid or does not belong to any of the three subspecies used in the analysis.

The data presented here represented a limited number of colonies from breeding apiaries 
in Poland where the purity of subspecies was controlled using instrumental insemination. In this situation there is possibility of inbreeding, which could accentuate differences between subspecies. For the discrimination functions to be made more reliable, data should be collected from more colonies representing various geographical locations. The new method of subspecies discrimination should be compared with the historical data collected by Ruttner (1988a) and with studies based on molecular methods (Cornuet and Garnery, 1991).

It needs to be stressed that, although standard morphometry of wings alone is marginally less effective than geometric morphometrics, standard morphometry provides good discrimination among subspecies (Radloff et al., 2003; Diniz-Filho et al., 2000; Ruttner et al., 2000). In some cases the traditional method should be preferred for comparison of results with findings from previous studies. Even when standard morphometry is used, the coordinates of all 18 landmarks should be preserved for future comparisons, because the 4 distances and the 11 angles of standard morphometry can be calculated using the coordinates of the landmarks, not the other way round.

\section{ACKNOWLEDGEMENTS}

I thank Michael Jacobs and two anonymous reviewers for helpful comments on earlier versions of this paper. This work was supported by MNiSW grant No. 2 P06Z 01328.

Utilisation de la morphométrie géométrique et de la morphométrie classique pour discriminer les sous-espèces d'abeilles (Apis mellifera).

Apis mellifera / morphométrie classique / morphométrie géométrique / sous-espèce / discrimination

Zusammenfassung - Die Unterscheidung von drei Unterarten der Honigbiene anhand von geometrischer Morphometrie und Standardmorphometrie. Die Unterarten der Honigbiene (Apis mellifera) werden üblicherweise unter Verwendung mit Standardmethoden der Morphometrie unterschieden, die überwiegend auf einer multivaria- ten Analyse von Abständen und Winkeln beruhen. In letzter Zeit wurde als eine weitere Methode die Geometrische Morphometrie entwickelt, die eine statistischen Analyse von durch cartesische Punktkoordinaten charakterisierter Formen verwendet. Beide Methoden wurden hier zur Unterscheidung von drei Unterarten der Honigbienen (A. m. mellifera, A. m. carnica und A. m. caucasica) anhand der Flügeladern verwendet. Die Flügeladerung wurde hierbei entweder durch die Koordinaten von 18 Aderkreuzungspunkten (Abb. 1) und deren Zentroidgröße oder durch 4 Abstände und 11 Flügeladerungswinkel beschrieben. Jede Unterart wurde durch 300 Arbeiterinnen aus 30 Völkern repräsentiert. Alle durch die Mittelwerte von jeweils 20 Arbeiterinnen beschriebene Völker wurden durch beide Methoden richtig klassifiziert (Abb. 2A, B). Einzelne Flügel wurden dagegen von der Geometrische Morphometrie in 83,8 \% der Fälle erfolgreich zugeordnet (Abb. 2C), im Falle der Standardmorphomerie waren es 84,9\% (Abb. 2D). Die Ergebnisse zeigen, dass die Geometrische Morphometrie für die Unterscheidung von Unterarten nur geringfügig zuverlässiger ist als die Standardmorphometrie. Die Klassifizierungsfunktionen (Appendix IIV) und die Mittelwerte der die Flügeladerung beschreibenden Variablen (Appendix V-VI) können zur Unterscheidung der Unterarten genutzt werden.

Geometrische Morphometrie / Standardmorphometrie / Unterscheidung der Unterarten / Apis mellifera

\section{REFERENCES}

Alpatov W.W. (1929) Biometrical studies on variation and races of the honey bee (Apis mellifera L.), Q. Rev. Biol. 4, 1-58.

Bookstein F.L. (1991) Morphometric tools for landmark data: Geometry and Biology, Cambridge University Press.

Cornuet J.M., Garnery L. (1991) Mitochondrial DNA variability in honeybees and its phylogeographic implications, Apidologie 22, 627-624.

Dedej S., Nazzi F. (1994) Two distances of forewing venation as estimates of wing size, J. Apic. Res. 33, 59-61.

Diniz-Filho J.A.F., Hepburn H.R., Radloff S., Fuchs S. (2000) Spatial analysis of morphological variation in African honeybees (Apis mellifera L.) on a continental scale, Apidologie 31, 191-204.

DuPraw E.J. (1964) Non-linnean taxonomy, Nature 202, 849-852.

Kauhausen D., Ruttner F. (1986) Apis mellifera carnica - Definition und Variabilität, Apidologie 17, 351-353. 
Kendall D.G., Barden D., Carne T.K., Le H. (1999) Shape and shape theory, John Wiley \& Sons, Chichester.

Radloff S., Hepburn R. (2000) Population structure and morphometric variance of the Apis mellifera scutellata group of honeybees in Africa, Genet. Mol. Biol. 23, 305-316.

Radloff S.E., Hepburn R., Bangay L.J. (2003) Quantitative analysis of intracolonial and intercolonial morphometric variance in honeybees, Apis mellifera and Apis cerana, Apidologie 34, 339-351.

Rohlf F.J. (2004) tpsSuper, superimposition and image averaging, version 1.13. Department of Ecology and Evolution, State University of New York at Stony Brook.

Rohlf F.J. (2005) tpsRelw, relative warps, version 1.42. Department of Ecology and Evolution, State University of New York at Stony Brook.

Rohlf F.J., Slice D. (1990) Extension of the Procrustes method for the optimal superimposition of landmarks, Syst. Zool. 39, 40-59.

Rostecki P., Samborski J., Prabucki J., ChudaMickiewicz B. (2007) A comparison of various hardware for the measurement of the cubital index, J. Apic. Sci. 51, 49-53.

Ruttner F. (1988a) Biogeography and taxonomy of honeybees, Springer, Berlin.

Ruttner F. (1988b) Breeding techniques and selection for breeding of the honeybee, BIBBA, London.
Ruttner F., Tassencourt L., Louveaux J. (1978) Biometrical-statistical analysis of the geographic variability of Apis mellifera L, Apidologie 9, 363381.

Ruttner F., Elmi M.P., Fuchs S. (2000) Ecoclines in the near east along 36 degrees $\mathrm{N}$ latitude in Apis mellifera L, Apidologie 31, 157-165.

StatSoft (2001) Statistica (data analysis software system), version 6 .

Steinhage V., Schroder S., Lampe K., Cremers A.B. (2007) Automated extraction and analysis of morphological features for species identification, in: MacLeod, N. (Ed.), Automated object identification in systematics: theory, approaches, and applications, CRC Press, Boca Raton, Florida.

Tofilski A. (2004) DrawWing, a program for numerical description of insect wings, J. Insect Sci. 4, 1-5.

Tofilski A. (2007) Automatic measurements of honeybee wings, in: MacLeod N. (Ed.), Automated object identification in systematics: theory, approaches, and applications, CRC Press, Boca Raton, Florida, pp. 289-298.

Whitfield C.W., Behura S.K., Berlocher S.H., Clark A.G., Johnston J.S., Sheppard W.S., Smith D.R., Suarez A.V., Weaver D., Tsutsui N.D. (2006) Thrice Out of Africa: Ancient and Recent Expansions of the Honey Bee, Apis mellifera, Science 314, 642-645.

Zelditch M.L., Swiderski D.L., Sheets H.D., Fink W.L. (2004) Geometric morphometrics for biologists: A primer, Elsevier Academic Presss, London. 
Apidologie 39 (2008) 558-563

\section{Online Material}


Appendix I. Classification functions for discrimination of three honeybee subspecies using mean of 10 forewings from one colony. The forewings were described by distances and angles between vein junctions.

\begin{tabular}{|c|c|c|c|c|c|c|c|c|c|c|}
\hline subspecies & a & b & d & A4 & B4 & D7 & E9 & G18 & $\mathrm{J} 10$ & K19 \\
\hline A. m. carnica & 18899.1 & 15223.9 & -536.1 & 331.9 & 119.8 & 94.7 & 43.2 & 22.9 & -26.9 & 28.3 \\
\hline A. m. caucasica & 18803.1 & 15291.1 & -581.7 & 330.4 & 118.8 & 96.0 & 43.1 & 21.9 & -25.9 & 27.4 \\
\hline A. m. mellifera & 18921.3 & 15640.5 & -597.3 & 332.5 & 120.6 & 95.2 & 38.0 & 22.0 & -27.2 & 28.4 \\
\hline
\end{tabular}

Appendix I (continued)

\begin{tabular}{|l|r|r|r|r|}
\hline subspecies & L13 & N23 & O26 & constant \\
\hline A. m. carnica & 72.3 & 82.7 & 29.3 & -29600.4 \\
\hline A. m. caucasica & 72.5 & 83.1 & 28.8 & -29342.6 \\
\hline A. m. mellifera & 75.3 & 84.5 & 29.6 & -29751.2 \\
\hline
\end{tabular}

Appendix II. Classification functions for discrimination of three honeybee subspecies using mean of 10 forewings from one colony. The forewings were described by the coordinates of vein junctions and centroid size (cs).

\begin{tabular}{|c|c|c|c|c|c|c|c|c|c|c|}
\hline subspecies & $1 x$ & $2 x$ & $3 y$ & $5 x$ & $6 x$ & $6 y$ & $7 x$ & $7 y$ & $10 x$ & $10 y$ \\
\hline A. m. carnica & -253978 & -115566 & -195657 & -92220 & -178295 & 324140 & 77289 & 294311 & 61072 & -94837 \\
\hline A. m. caucasica & -254228 & -113132 & -194594 & -91725 & -178602 & 324907 & 78967 & 301 & 62966 & -95229 \\
\hline A. m. mellifera & -255299 & -112018 & -193365 & -91045 & -177039 & 320561 & 77541 & 297520 & 62173 & -93404 \\
\hline
\end{tabular}

Appendix II (continued)

\begin{tabular}{|c|c|c|c|c|c|c|c|c|c|c|}
\hline subspecies & $11 x$ & $11 y$ & $12 x$ & $12 y$ & $13 x$ & $14 y$ & $15 y$ & $16 x$ & $17 y$ & $18 x$ \\
\hline A. m. carnica & 30505 & 88138 & 12618 & -256408 & 190543 & -30448 & 55858 & 262271 & -58345 & 368756 \\
\hline A. m. caucasica & 28393 & 91636 & 16447 & -257139 & 189415 & -31670 & 56254 & 263410 & -55909 & 370060 \\
\hline A. m. mellifera & 30969 & 90009 & 13660 & -254730 & 190712 & -32329 & 57650 & 263774 & -56837 & 368259 \\
\hline
\end{tabular}

Appendix II (continued)

\begin{tabular}{|l|r|r|r|}
\hline subspecies & \multicolumn{1}{|l|}{$18 \mathrm{y}$} & cs & \multicolumn{1}{c|}{ constant } \\
\hline A. m. carnica & 143225 & 1781 & -245328 \\
\hline A. m. caucasica & 142248 & 1710 & -245289 \\
\hline A. m. mellifera & 145459 & 1762 & -244317 \\
\hline
\end{tabular}

Appendix III. Classification functions for discrimination of three honeybee subspecies using single forewing. The forewings were described by distances and angles between vein junctions.

\begin{tabular}{|c|c|c|c|c|c|c|c|c|c|c|}
\hline subspecies & a & $b$ & C & d & A4 & B4 & D7 & E9 & G18 & $\mathrm{J} 10$ \\
\hline A. m. carnica & 4075.34 & 3155.16 & 615.00 & 155.25 & 83.30 & 28.69 & 17.15 & 6.32 & 9.81 & 4.06 \\
\hline A. m. caucasica & 4041.61 & 3152.67 & 613.02 & 140.25 & 82.94 & 28.40 & 17.55 & 6.27 & 9.66 & 4.18 \\
\hline A. m. mellifera & 4061.79 & 3217.39 & 631.31 & 135.87 & 83.07 & 28.66 & 17.45 & 5.23 & 9.76 & 3.92 \\
\hline
\end{tabular}

Appendix III (continued)

\begin{tabular}{|c|c|c|c|c|c|c|}
\hline subspecies & $\mathrm{J} 16$ & K19 & L13 & N23 & $\mathrm{O} 26$ & constant \\
\hline A. m. carnica & 14.61 & 11.67 & 6.30 & 8.94 & 5.63 & -7994.24 \\
\hline A. m. caucasica & 14.57 & 11.42 & 6.50 & 8.92 & 5.61 & -7904.97 \\
\hline A. m. mellifera & 14.65 & 11.67 & 6.73 & 9.11 & 5.70 & -7992.28 \\
\hline
\end{tabular}

Appendix IV. Classification functions for discrimination of three honeybee subspecies using single forewing. The forewings were described by the coordinates of vein junctions and centroid size (cs).

\begin{tabular}{|c|c|c|c|c|c|c|c|c|c|c|}
\hline ecies & $1 x$ & $2 x$ & $2 y$ & $3 y$ & $4 x$ & $4 y$ & $5 x$ & $5 y$ & $6 x$ & $6 y$ \\
\hline A. $n$ & -88396.2 & -65395.6 & 73668.5 & -15901.9 & -56302.1 & 7.5 & -72589.8 & 30 & 0.6 & \\
\hline A. $n$ & 8.6 & 9.1 & 9.8 & 024.0 & .7 & .7 & -72311.2 & 8.8 & 20.1 & 1 \\
\hline A. m. mellifera & -88639.9 & -64886.0 & 73918.4 & -15368.5 & -56452.3 & 48004.1 & -72417.3 & 30989.6 & -42325.0 & 124364.6 \\
\hline
\end{tabular}


Appendix IV (continued)

\begin{tabular}{|l|r|r|r|r|r|r|r|r|r|r|}
\hline subspecies & $7 \mathrm{x}$ & $\mathrm{y}$ & $\mathrm{y}$ & $\mathrm{y}$ & $10 \mathrm{x}$ & $10 \mathrm{y}$ & $11 \mathrm{x}$ & $11 \mathrm{y}$ & $12 \mathrm{x}$ & $12 \mathrm{y}$ \\
\hline A. m. carnica & 6972.5 & 30361.6 & 36842.6 & 15680.3 & -3412.0 & 9523.9 & -4109.3 & 18248.3 & -5526.0 & -32558.7 \\
\hline A. m. caucasica & 6890.7 & 30536.5 & 36691.1 & 15691.6 & -3334.8 & 9724.0 & -4279.7 & 18527.9 & -5063.9 & -32625.1 \\
\hline A. m. mellifera & 6955.8 & 30331.7 & 36934.4 & 15735.7 & -3343.4 & 9724.1 & -4028.5 & 18385.1 & -5567.3 & -32461.8 \\
\hline
\end{tabular}

Appendix IV (continued)

\begin{tabular}{|l|r|l|l|l|l|l|l|l|l|l|}
\hline subspecies & $13 \mathrm{x}$ & $13 \mathrm{y}$ & $14 \mathrm{x}$ & $14 \mathrm{y}$ & $16 \mathrm{y}$ & $17 \mathrm{x}$ & $17 \mathrm{y}$ & $18 \mathrm{x}$ & $\mathrm{cs}$ & constant \\
\hline A. m. carnica & 6861.9 & -33318.8 & 43010.6 & 60227.6 & -49361.7 & 91985.6 & -42640.4 & 42975.2 & 1230.8 & -87421.8 \\
\hline A. m. caucasica & 6769.1 & -33260.3 & 42814.2 & 60145.3 & -49173.1 & 91785.3 & -42139.8 & 42901.6 & 1219.2 & -87010.2 \\
\hline A. m. mellifera & 6781.1 & -33360.4 & 42988.6 & 59905.9 & -49487.7 & 91822.5 & -42874.5 & 42687.1 & 1226.9 & -87019.5 \\
\hline
\end{tabular}

Appendix $V$. Mean values of distances and angles describing forewing.

\begin{tabular}{|l|c|c|c|c|c|c|r|r|r|r|}
\hline subspecies & $\mathrm{a}$ & $\mathrm{b}$ & $\mathrm{c}$ & $\mathrm{d}$ & $\mathrm{A} 4$ & $\mathrm{~B} 4$ & \multicolumn{1}{c|}{$\mathrm{D} 7$} & $\mathrm{E} 9$ & \multicolumn{1}{c|}{$\mathrm{G} 18$} & $\mathrm{~J} 10$ \\
\hline A. m. carnica & 0.626176 & 0.202318 & 0.883217 & 2.010233 & 28.09853 & 108.5262 & 93.9761 & 22.52686 & 98.93501 & 49.45519 \\
\hline A. m. caucasica & 0.525944 & 0.231025 & 0.851363 & 1.956611 & 32.03879 & 103.5628 & 101.3087 & 20.90850 & 98.67491 & 51.30637 \\
\hline A. m. mellifera & 0.533505 & 0.269788 & 0.865971 & 1.973236 & 29.87412 & 104.2515 & 100.8813 & 18.64765 & 99.93541 & 48.31194 \\
\hline all & 0.561875 & 0.234377 & 0.866851 & 1.980027 & 30.00381 & 105.4468 & 98.7220 & 20.69434 & 99.18178 & 49.69117 \\
\hline
\end{tabular}

Appendix V (continued)
\begin{tabular}{|l|r|c|c|c|c|}
\hline subspecies & \multicolumn{1}{c|}{ J16 } & \multicolumn{1}{c|}{ K19 } & L 13 & N23 & O 26 \\
\hline A. m. carnica & 101.1183 & 80.90713 & 13.92240 & 95.33635 & 35.40521 \\
\hline A. m. caucasica & 99.4224 & 79.20062 & 14.55574 & 93.85485 & 35.42705 \\
\hline A. m. mellifera & 101.7870 & 82.38411 & 14.94815 & 95.80810 & 37.32251 \\
\hline all & 100.7759 & 80.83062 & 14.47543 & 94.99977 & 36.05159 \\
\hline
\end{tabular}

Appendix VI. Mean values of aligned coordinates and centroid size (cs) describing forewing.

\begin{tabular}{|l|l|l|l|l|l|l|l|l|l|l|}
\hline subspecies & $1 \mathrm{x}$ & $\mathrm{x}$ & $\mathrm{x}$ & $\mathrm{x}$ & $\mathrm{x}$ & $3 \mathrm{y}$ & $4 \mathrm{x}$ & $4 \mathrm{y}$ & $5 \mathrm{x}$ & $5 \mathrm{y}$ \\
\hline A. m. carnica & -0.355517 & -0.060097 & -0.322758 & -0.064247 & -0.237353 & 0.077279 & -0.232895 & -0.012259 & -0.228089 & -0.157861 \\
\hline A. m. caucasica & -0.352307 & -0.056946 & -0.313726 & -0.059965 & -0.249671 & 0.077325 & -0.238204 & -0.013620 & -0.217884 & -0.154844 \\
\hline A. m. mellifera & -0.359813 & -0.057543 & -0.315363 & -0.058972 & -0.250742 & 0.076119 & -0.240673 & -0.011782 & -0.219051 & -0.153627 \\
\hline all (reference) & -0.355879 & -0.058195 & -0.317282 & -0.061061 & -0.245922 & 0.076907 & -0.237257 & -0.012554 & -0.221675 & -0.155444 \\
\hline
\end{tabular}

Appendix VI (continued)

\begin{tabular}{|l|l|l|l|l|l|l|l|l|l|l|}
\hline subspecies & $6 \mathrm{x}$ & $6 \mathrm{y}$ & $7 \mathrm{x}$ & $7 \mathrm{y}$ & $8 \mathrm{x}$ & $8 \mathrm{y}$ & $9 \mathrm{x}$ & $9 \mathrm{y}$ & $10 \mathrm{x}$ & $10 \mathrm{y}$ \\
\hline A. m. carnica & -0.108757 & 0.088653 & -0.022297 & 0.137749 & -0.042552 & 0.109308 & 0.030825 & 0.051612 & -0.027858 & 0.011561 \\
\hline A. . caucasica & -0.113698 & 0.089778 & -0.026700 & 0.140994 & -0.048968 & 0.109797 & 0.028678 & 0.050614 & -0.022371 & 0.014001 \\
\hline A. m. mellifera & -0.114157 & 0.084405 & -0.024146 & 0.135741 & -0.044180 & 0.106542 & 0.030564 & 0.048958 & -0.020365 & 0.014147 \\
\hline all (reference) & -0.112204 & 0.087612 & -0.024381 & 0.138161 & -0.045233 & 0.108549 & 0.030022 & 0.050395 & -0.023532 & 0.013236 \\
\hline
\end{tabular}

Appendix VI (continued)

\begin{tabular}{|l|l|l|l|l|l|l|l|l|l|l|}
\hline subspecies & $11 \mathrm{x}$ & $11 \mathrm{y}$ & $12 \mathrm{x}$ & $12 \mathrm{y}$ & $13 \mathrm{x}$ & $13 \mathrm{y}$ & $14 \mathrm{x}$ & $14 \mathrm{y}$ & $15 \mathrm{x}$ & $15 \mathrm{y}$ \\
\hline A. m. carnica & 0.045069 & -0.044934 & 0.054779 & -0.115304 & 0.085023 & -0.168346 & 0.119209 & 0.124176 & 0.168832 & 0.074706 \\
\hline A. m. caucasica & 0.048791 & -0.045497 & 0.059946 & -0.117527 & 0.089810 & -0.170703 & 0.112704 & 0.126120 & 0.168115 & 0.072901 \\
\hline A. m. mellifera & 0.049433 & -0.042430 & 0.057038 & -0.113441 & 0.087805 & -0.165912 & 0.119559 & 0.120789 & 0.168869 & 0.071540 \\
\hline all (reference) & 0.047764 & -0.044287 & 0.057254 & -0.115424 & 0.087546 & -0.168321 & 0.117157 & 0.123695 & 0.168605 & 0.073049 \\
\hline
\end{tabular}

Appendix VI (continued)
\begin{tabular}{|l|l|l|l|l|l|l|l|}
\hline subspecies & $16 \mathrm{x}$ & $16 \mathrm{y}$ & $17 \mathrm{x}$ & $17 \mathrm{y}$ & $18 \mathrm{x}$ & $18 \mathrm{y}$ & cs \\
\hline A. m. carnica & 0.308844 & 0.003809 & 0.373590 & -0.004098 & 0.391902 & -0.051708 & 5.832256 \\
\hline A. m. caucasica & 0.308785 & 0.001396 & 0.374397 & -0.006705 & 0.392301 & -0.057115 & 5.731783 \\
\hline A. m. mellifera & 0.310304 & 0.001976 & 0.374660 & -0.005538 & 0.390259 & -0.050970 & 5.793806 \\
\hline all (reference) & 0.309311 & 0.002394 & 0.374216 & -0.005447 & 0.391487 & -0.053265 & 5.785948 \\
\hline
\end{tabular}

